\title{
Effect of Pretreatment on the Quality Characteristics of Osmodried Mango Slices
}

\author{
G. Gurumeenakshi* and N. Varadharaju
}

Centre for Post Harvest Technology, Agricultural Engineering College \& Research Institute, Tamil Nadu Agricultural University, Coimbatore - 641003, Tamil Nadu, India

*Corresponding author

\section{A B S T R A C T}

Keywords

Mango,

Pretreatment,

Osmotic agent,

Dehydration

Article Info

Accepted:

17 October 2019

Available Online:

10 November 2019
Mango is a fruit which is highly relished in both raw and processed form. Various studies have indicated that pretreatment of fruits prior to osmotic dehydration improved the quality of the product. Hence an attempt was made to study the effect of various pretreatments in the quality characteristics of osmo dried fruits. Bangalora and Pairi varieties of mango fruits were washed, peeled, destoned and cut to slices. The slices were given two pretreatments viz., soaking the fruit slices in a solution of citric acid, ascorbic acid for $30 \mathrm{~min}$. After pretreatment the fruit slices were soaked in the osmotic agent (sugar syrup) for $18 \mathrm{~h}$ followed by dehydration, cooling and packing. The dried fruit slices were packed in metallised polypropylene packs and subjected to shelf life studies for a period of 180 days. Analysis of the physiochemical qualities, microbial and sensory qualities of the fruit slices during storage, indicated that the osmo dried fruit samples pretreated with ascorbic acid had retained highly acceptable qualities.

\section{Introduction}

Mango known as "King of Asiatic fruits", originated in India is admired all over the world. In area of production and nutritive value no other fruit can compete with it. Fruits are perishable, seasonal and region specific. They are sometimes wasted in large quantities due to the absence of facilities and know how for proper handling, storage, distribution and marketing. Hence, fruit processing becomes critical as this would mop up surpluses at farm level and ensure fair price and also make them available at reasonable price for the consumer all through the year. Osmotic dehydration is a novel technique for the production of shelf stable, nutritious and tasty products. Osmo dried fruits serve as an excellent snack food 
and are very handy. These can also be used in bakery products as food adjuncts. Moreover, dried fruits are nutritious as they are highly concentrated sources of sugar, vitamins and minerals (Shah et al., 2000). Generally the technology of fruit processing is determined by the properties of the raw material and the quality to be maintained. Studies of Amitabh et al., (2000) Sudhagar (2001), Vijayakumar (2002) and Gupta et al., (2002) have indicated that pretreatment of such as blanching or soaking in a solution containing citric acid or KMS improved the quality of osmo dried mango, papaya and pear. Hence, the present investigation was undertaken with the objective to study the effect of pretreatment on the nutritional, microbial and sensory quality of osmo dried fruit slices before and after storage.

\section{Materials and Methods}

Bangalora variety $\left(\mathrm{V}_{1}\right)$ and Pairi variety $\left(\mathrm{V}_{2}\right)$ of mango was purchased from the local market. The other ingredients namely sugar, food grade citric acid, ascorbic acid, were purchased from the local stores. All the chemicals and glasswares used in the study were of standard companies (Merck and Borosil).

Fresh firm, about to ripe fruits of uniform size and shape without any blemishes were selected, washed, peeled, destoned and cut into slices $(6 \times 2 \mathrm{~cm})$.

The following pretreatments were imposed.

\begin{tabular}{|l|l|}
\hline $\mathrm{T}_{1}$ & Citric acid $(0.5 \%)$ \\
\hline $\mathrm{T}_{2}$ & $\begin{array}{l}\text { Ascorbic acid solution } \\
(0.5 \%)\end{array}$ \\
\hline
\end{tabular}

For preparing the above solutions, the required chemicals were weighed and dissolved in the measured amount of water $(1000 \mathrm{ml})$ and stirred. The solutions were filtered to remove any debris which would otherwise affect the quality of the product. The filtered solutions were used as soak solutions for pretreatments.

The sliced fruits were soaked in the respective solutions for a period of 30 minutes. The fruit slices that were not given any pretreatment served as control.

The proportion of ingredients used for the preparation of osmotic agent includes sugar $(600 \mathrm{~g})$, water $(400 \mathrm{ml})$, citric acid $(10 \mathrm{~g})$ and KMS (0.1g).

Sugar was added to water and mixed thoroughly well. After adding sugar the contents were heated to $100{ }^{0} \mathrm{C}$. Citric acid (3g) was added to sugar syrup $\left(60^{\circ}\right.$ Brix $)$ while boiling to purify the sugar syrup. The brix of the syrup was checked using hand refractometer. The syrup was filtered through a clean muslin cloth and cooled to $50{ }^{\circ} \mathrm{C}$.

The treated and control fruit slices were soaked in the osmotic agent separately. The fruit slices to osmotic agent ratio was 1:1. During the process of osmosis the temperature of the osmotic agent was maintained at $50^{\circ} \mathrm{C}$ for the first two hours to facilitate effective osmosis. After $2 \mathrm{~h}$ the temperature of the osmotic agent was brought down to ambient condition. Citric acid ( $7 \mathrm{~g}$ ) was added to the osmotic agent containing the fruit slice, followed by the addition of KMS (100mg). The fruit slices were allowed to remain in the osmotic agent for $18 \mathrm{~h}$.

After $18 \mathrm{~h}$, the fruit slices were removed from the osmotic agent, arranged in trays and dried in a cabinet drier at $60^{\circ} \mathrm{c}$ for $6 \mathrm{~h}$ and cooled before packing.

The dried fruit slices were surface coated with powdered sugar and packed in metallised polypropylene packs and stored at ambient conditions for shelf life studies. The 
nutritional, microbial and sensory qualities were periodically analysed at regular intervals throughout the storage period of 180 days.

The following qualities of the stored osmo dried slices were periodically (once in 30 days) evaluated.

Moisture, TSS, acid content, reducing and total sugars, $\beta$ carotene, ascorbic acid and crude fibre were analysed using standard methods AOAC, 2007. The total plate count was determined by serial dilution technique and plating method as given by Istavan Kiss (1974). The osmo dried fruit slices were assessed for colour, texture, flavor, taste and over all acceptability by a panel of 15 semi trained judges using nine point hedonic scale (Watts et al., 1989). The cost of preparation of the osmo dried mango slices were calculated using the fixed and the variable cost involved in the course of processing. The data obtained from two replications were subjected to statistical analysis by applying completely randomized block design (Gomez and Gomez, 1984).

\section{Results and Discussion}

The changes observed in the nutrient content of the osmo dried fruit slices during storage are presented in Table 1.

It could be inferred that the initial moisture content ranged from 15.70 to 16.90 for $\mathrm{V}_{1}$ and 14.90 to 16.75 for $\mathrm{V}_{2}$ (g per $100 \mathrm{~g}$ respectively). After 180 days of storage a slight increase in moisture was observed in all the samples irrespective of the treatment and variety.

Among the treatments the highest moisture level was observed in the $T_{0}$ followed by $T_{1}$ and $\mathrm{T}_{2}$ for both the varieties. Studies of Amitabh et al., (2000) indicated that the moisture content of osmo dried mango slices ranged from 11.00 to 13.99 which had increased from 11.65 to 14.29 with varied pretreatments.

The changes in the total soluble solids of the osmo dried fruit slices are presented in Table 1. There was no much difference in the TSS of the fruit slices within the treatment. However significant differences were observed between the control and treatments and as well as within the varieties. Among the treatments the highest TSS was found in $\mathrm{T}_{2}$ and lowest in $\mathrm{T}_{0}$ irrespective of the variety. After 180 days of storage negligible loss of TSS occurred in the osmo dried slices. Vijayakumar (2002) reported that the TSS of osmo dried fruit slices to range between 62.5 and $65.7^{\circ} \mathrm{bx}$. He also stated that there was no much change in the TSS of the osmo dried mango slices during storage. The present investigation is in line with the above study.

A significant difference existed in the acid content among the treatments, varieties and storage period as it is evident from the Table 1. The highest acidity was exhibited by the samples treated with citric acid followed by ascorbic acid in both the varieties during the initial storage period. The acidity of the control samples were lesser than the treated samples irrespective of the variety. During storage a slight increase in the acidity was noted and the increase was more pronounced in $\mathrm{T}_{0}$ and less in $\mathrm{T}_{2}$. The osmodried mango slices had 0.45 and 1.37 per cent of acidity (Mishra and Tomar, 2000 and Amitabh et al., 2000). The values noted in the present study was more than the values reported by Mishra and Tomar (2000) and lesser than by Amitabh et al., (2000). This might be due to the variety and treatment used for the present study.

The total sugar content ranged from 60.85 to $62.19 \mathrm{~g}$ per $100 \mathrm{~g}$ initially. Similarly for $\mathrm{V}_{2}$ the initial and final total sugars ranged from 62.50 to 63.52 and 63.08 to $63.48 \mathrm{~g}$ per $100 \mathrm{~g}$ 
respectively. A significant difference was observed in the reduction of total sugars between the treatment, varieties and packaging materials. Amitabh et al., (2000) reported that the osmo dried mango slices had the total sugars in the range from 60 to $65 \mathrm{mg} / 100 \mathrm{~g}$. They also observed a loss in the total sugars during storage. A similar trend was observed in the present study also.

Contrary to total sugars, there was a slight increase in the reducing sugars of the osmo dried mango slices during storage period. The increase was more in the control samples than in the treated ones. Of the treatments, $T_{2}$ showed the minimum increase followed by $\mathrm{T}_{1}$. The reducing sugar of $\mathrm{V}_{2}$ was slightly more than $\mathrm{V}_{1}$ during the initial storage period, and same trend continued throughout the storage, which might be due to the varietal difference. The reducing sugar content of osmodried mango slices were 11.66 and 13.32 per cent (Mishra and Tomar, 2000) and 13.21 and 13.86 per cent (Vijayakumar, 2002) before and after storage respectively.

Osmo dried mango slices had an appreciable amount of $\beta$ carotene and the initial $\beta$ carotene ranged from 1225 to $1800\left(\mathrm{~V}_{1}\right)$ and 1136 to $1652\left(\mathrm{~V}_{2}\right) . \mu \mathrm{g}$ per $100 \mathrm{~g}$. A significant difference was noted in the $\beta$ carotene content between the control and the treatment. It was comparatively more in the treated samples irrespective of the varieties. This showed that pretreatment of fruit slices prior to osmo dehydration exert an influence in retention of $\beta$ carotene. During storage there was a reduction in the $\beta$ carotene and the reduction was more prominent in the control than treatment. Among the treatment samples $\mathrm{T}_{2}$ showed the highest retention of $\beta$ carotene, while $T_{1}$ recorded the lowest retention. The final $\beta$ carotene content ranged from 985 to 1740 and 835 to $1580 \mu \mathrm{g}$ per $100 \mathrm{~g}$ for $\mathrm{V}_{1}$ and $\mathrm{V}_{2}$ respectively. Vijayakumar (2002) indicated a reduction in the $\beta$ carotene content and reported the values ranged between 322.80 to
$369.40 \mu \mathrm{g}$ per $100 \mathrm{~g}$ as against the initial amount of 385 to $392.20 \mu \mathrm{g}$ per $100 \mathrm{~g}$.

Similar to $\beta$ carotene the pretreatments exerted a positive influence in the retention of ascorbic acid during processing of the osmo dried mango slices as seen from Table 1 . The highest ascorbic acid was exhibited by $T_{2}$ while the lowest was in $\mathrm{T}_{0}$ in both the varieties, which might be due to the difference in the pretreatments given. The same trend was maintained throughout the storage period. The ascorbic acid content after 180 days of storage ranged from 7.68 to 11.56 for $\mathrm{V}_{1}$ and 5.43 to $9.34 \mathrm{mg}$ per $100 \mathrm{~g}$ for $\mathrm{V}_{2}$ respectively. Vijayakumar (2002) had also reported a loss in ascorbic acid content during processing and storage of mango slices.

The initial crude fibre content for $\mathrm{V}_{1}$ ranged from 0.63 to 0.65 and for $V_{2}$ ranged from 0.70 to $0.71 \mathrm{~g}$ per $100 \mathrm{~g}$. A non significant difference was observed in the crude fibre between the treatments, varieties and storage period. During storage there was a slight reduction and the values ranged from 0.62 to 0.64 for $\mathrm{V}_{1}$ and 0.64 to 0.71 for $\mathrm{V}_{2} \mathrm{~g}$ per $100 \mathrm{~g}$ respectively.

Table 2 gives information on the bacterial, fungal and yeast load of the osmo dried slices during storage. Initially there was no microbial load in all the treatments and varieties including the control. After 180 days of storage there was a slight increase in the bacterial load in all the samples, while no fungal and yeast colonies was found in $T_{1}$ and $\mathrm{T}_{2}$ in both the varieties. The mean organoleptic scores of the osmo dried mango slices were measured. During the initial storage period, the colour was bright yellow for the samples of $T_{1}$ to $T_{2}$ and dull yellow without browning for $\mathrm{T}_{0}$ of $\mathrm{V}_{1}$. For $\mathrm{V}_{2}$ the colour of $T_{1}$ to $T_{2}$ was bright yellow with the red tinch and for $\mathrm{T}_{0}$ it was dull yellow with a red tinch without browning. 
Table.1 Quality Characteristics of osmo dried mango during storage(per 100g)

\begin{tabular}{|c|c|c|c|c|c|c|c|}
\hline \multirow[t]{2}{*}{ Nutrients } & \multirow{2}{*}{$\begin{array}{c}\text { Storage } \\
\text { period }\end{array}$} & \multicolumn{3}{|c|}{ V1 } & \multicolumn{3}{|c|}{ V2 } \\
\hline & & $\mathrm{T}_{0}$ & $\mathrm{~T}_{1}$ & $\mathrm{~T}_{2}$ & $\mathrm{~T}_{0}$ & $\mathrm{~T}_{1}$ & $\mathrm{~T}_{2}$ \\
\hline \multirow[t]{2}{*}{ Moisture(g) } & Initial & 15.70 & 16.00 & 16.90 & 14.90 & 16.00 & 16.70 \\
\hline & Final & 16.59 & 16.90 & 16.95 & 15.83 & 16.25 & 16.75 \\
\hline \multirow[t]{2}{*}{ TSS $\left({ }^{0} \mathbf{b x}\right)$} & Initial & 61.00 & 63.00 & 63.50 & 63.50 & 64.00 & 64.50 \\
\hline & Final & 60.80 & 62.50 & 63.00 & 63.55 & 64.50 & 64.50 \\
\hline \multirow[t]{2}{*}{ Acidity(\%) } & Initial & 0.600 & 0.856 & 0.820 & 0.618 & 0.830 & 0.795 \\
\hline & Final & 0.618 & 0.869 & 0.822 & 0.638 & 0.848 & 0.805 \\
\hline \multirow{2}{*}{$\begin{array}{c}\text { Total } \\
\text { sugars(g) }\end{array}$} & Initial & 60.85 & 61.48 & 62.19 & 62.50 & 63.28 & 63.52 \\
\hline & Final & 60.00 & 61.13 & 62.08 & 62.28 & 63.08 & 63.48 \\
\hline \multirow{2}{*}{$\begin{array}{l}\text { Reducing } \\
\text { sugars (g) }\end{array}$} & Initial & 12.30 & 15.15 & 15.58 & 13.25 & 16.60 & 16.85 \\
\hline & Final & 13.08 & 15.48 & 15.73 & 14.73 & 17.03 & 16.93 \\
\hline \multirow{2}{*}{$\begin{array}{c}\beta \\
\text { carotene }(\mu \mathrm{g})\end{array}$} & Initial & 1225 & 1720 & 1800 & 1136 & 1610 & 1652 \\
\hline & Final & 985 & 1620 & 1740 & 835 & 1470 & 1580 \\
\hline \multirow{2}{*}{$\begin{array}{l}\text { Ascorbic } \\
\text { acid (mg) }\end{array}$} & Initial & 8.25 & 9.00 & 11.63 & 6.07 & 7.20 & 9.43 \\
\hline & Final & 7.68 & 8.94 & 11.56 & 5.43 & 7.12 & 9.34 \\
\hline \multirow{2}{*}{$\begin{array}{l}\text { Crude fibre } \\
\text { (g) }\end{array}$} & Initial & 0.65 & 0.63 & 0.65 & 0.71 & 0.70 & 0.71 \\
\hline & Final & 0.64 & 0.62 & 0.64 & 0.64 & 0.69 & 0.71 \\
\hline
\end{tabular}

$\mathrm{V}_{1}$ - Bangalora., $\mathrm{V}_{2}$ - Pairi, $\mathrm{T}_{0^{-}}$- Control, $\mathrm{T}_{1}$ - Citric acid, $\mathrm{T}_{2}$ - Ascorbic acid

Table.2 Microbial load of mango during storage (cfu/g)

\begin{tabular}{|c|c|c|c|c|c|c|c|}
\hline Microbial load & $\begin{array}{c}\text { Storage } \\
\text { period }\end{array}$ & $\mathrm{T}_{0}$ & $\mathrm{~T}_{1}$ & $\mathrm{~T}_{2}$ & $\mathrm{~T}_{0}$ & $\mathrm{~T}_{1}$ & $\mathrm{~T}_{2}$ \\
\hline Bacteria $\times \mathbf{1 0}^{-\mathbf{6}}$ & Initial & 0 & 0 & 0 & 0 & 0 & 0 \\
\cline { 2 - 9 } & Final & 3.2 & 2.8 & 1.0 & 3.5 & 3.0 & 2.2 \\
\hline \multirow{2}{*}{ Fungi $\times \mathbf{1 0}^{-3}$} & Initial & 0 & 0 & 0 & 0 & 0 & 0 \\
\cline { 2 - 9 } & Final & 1.2 & 1 & 0 & 1.3 & 1 & 1 \\
\hline \multirow{2}{*}{ Yeast $\times \mathbf{1 0}^{-2}$} & Initial & 0 & 0 & 0 & 0 & 0 & 0 \\
\cline { 2 - 8 } & Final & 1 & 0.80 & 0 & 1 & 0.80 & 0.50 \\
\hline
\end{tabular}

Among the treatments the samples of $\mathrm{T}_{2}$ obtained the maximum score for colour in both $\mathrm{V}_{1}$ and $\mathrm{V}_{2}$, which was maintained throughout the storage period. During storage there was a loss of the colour and a slight brown tinch appeared in the control samples in both the varieties. There was a reduction in the scores for colour during storage and the highest reduction was for $\mathrm{T}_{0}$ and lowest in $\mathrm{T}_{2}$ for both $\mathrm{V}_{1}$ and $\mathrm{V}_{2}$. The treated osmo dried samples of both the varieties had soft and pliable texture which was highly acceptable, while the control samples were firm. During storage the highly acceptable texture was maintained only by the treated samples while the control samples became soggy irrespective of the variety. The highest scores for flavour and taste was obtained by $T_{2}, T_{1}$ and $T_{0}$ in 
both the varieties, which was maintained throughout the storage period. The samples of $\mathrm{T}_{2}$ had highly acceptable mango flavor and sweet taste. The results of the sensory evaluation revealed that osmo dried fruit slices of $\mathrm{V}_{1}$ were more acceptable than $\mathrm{V}_{2}$.

The unit cost of osmo dried mango slices (10 g) was Rs. 1.85, which was cheaper than sugar boiled confectioneries and chocolates.

The study concluded that Bangalora variety is more suitable for osmotic dehydration. Among the pretreatments, soaking of the fruit slices in a solution containing ascorbic acid + could be very effective in retaining the nutritional properties during storage. $\mathrm{T}$ he product scored highly acceptable sensory attributes.

\section{References}

Amitabh, R., D. Singh and M.C. Tomar. 2000. Studies on osmotic dehydration of some mango varieties of ripe mangoes grown in Uttarpradesh. Indian Food Packer. 54(3): 66-70.

AOAC. 2007. Official methods of Analysis. $18^{\text {th }}$ Edition. Association of Official Analytical Chemists. Washington DC.

Gomez, K.H and A.A. Gomez. 1984. Statistical procedure for Agricultural Research. II edn. John Wiley and Sons. New York. Pp. 381.

Gupta, R., M. Kalia and S.R. Malhotra. 2002.
Preparation and storage of citrus peel candy of Darunj (Citrus medica). Beverage and Food World. 29(2): 4546.

Mehta, A., P.S. Ranote and A.S. Bawa. 2002. Indian Food processing Industry: Quality and Control aspects. Indian Food Industry. 21(1): 37-40.

Mishra. J and M.C. Tomar. 2000. Studies on the preparation and storage of intermediate moisture ripe mango slices of Dashehari cultivar. Indian Food Packer. 54(2): 61-66.

Sudhagar. T. 2001. Value added products from pears. M.Sc thesis. Dept. of Food science and Nutrition. Home Science College and Research Institute. Tamil Nadu Agricultural University. Madurai.

Shah, A., D.K. Dasgupta and S.S. Arya. 2000. Value added products for development of horticulture produce. Indian Horticulture. 45(2): 18-21.

Vijayakumar, A. 2002. Studies on osmotic dehydration characteristics of selected mango cultivars. M.Sc thesis. Dept. of Food science and Nutrition. Home Science College and Research Institute. Tamil Nadu Agricultural University. Madurai.

Watts. B.M., G.L. Ylimabi, L.E. Jeffery and L.G. Elias. 1989. Basic sensory methods for food evaluation. IDRC. Ottawa. Canada. Pp. 58-65.

\section{How to cite this article:}

Gurumeenakshi, G. and Varadharaju, N. 2019. Effect of Pretreatment on the Quality Characteristics of Osmodried Mango Slices. Int.J.Curr.Microbiol.App.Sci. 8(11): 1905-1910. doi: https://doi.org/10.20546/ijcmas.2019.811.223 